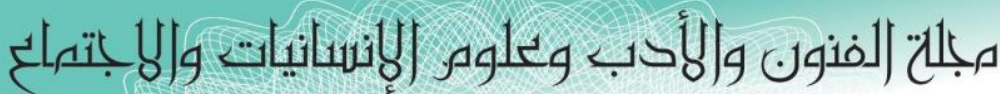

Journal of Arts, Literature, Humanities and Social Sciences

ISSN online: 2414 - 3383

ISSN print: 2616 - 3810

العدد (39) حزيران - يونيو 2019

\section{Electronic Commerce: Administrative and Legal Framework}

\author{
Hawre Nuraddin Sabir \\ Department of Law, College of Law, Salahaddin University, and Visiting Lecturer at \\ Lebanese French University. \\ hawre.nuradin@gmail.com \\ Zana Majed Sadq \\ Department of Management and Accounting, Faculty of Humanities and Social \\ Sciences, Koya University, Iraq, and Visiting Lecturer at Management Department, \\ Collage of Administration and Finance, Knowledge University, Kurdistan Region/ Iraq. \\ zana.sadq@koyauniversity.org
}

Dr. Vian Sulaiman Hama Saeed,

Department of Management and Accounting, Faculty of Humanities and Social Sciences, Koya University, Iraq, and Visiting Lecturer at Accounting Department, Collage of Administration and Finance, Knowledge University, Kurdistan Region/ Iraq. vian.alsalihy@koyauniversity.org

\begin{abstract}
Over the last period, there have been many significant developments in information, communications and technologies, leading to a change in the nature and lifestyle of all consumers, in developed and developing countries. Consumers can now shop and conducting commercial and banking transactions from home. Further, consumers can pay electronically using a computer without effort. It has been a big and fast electronic advance that impact on the process of connecting the world to electronic networks that made it a closely interconnected cell. However, as soon as it emerged, the network was accompanied unexpected attacks and infringement, which has led to the emergence of many new forms of crime, deception and fraud. Leading to the emergence of active attempts to find methods and means to reduce such violations and attacks, and then combat deception and fraud associated with it. Although some consumers may refuse to deal with modern technologies for their fear of fraud and deception, even the size of electronic commerce has become unstoppable, especially for commercial and governmental activities. Based on the above, this study will attempt to present and make some recommendations to protect consumers in the Electronic Commerce Contracts.
\end{abstract}




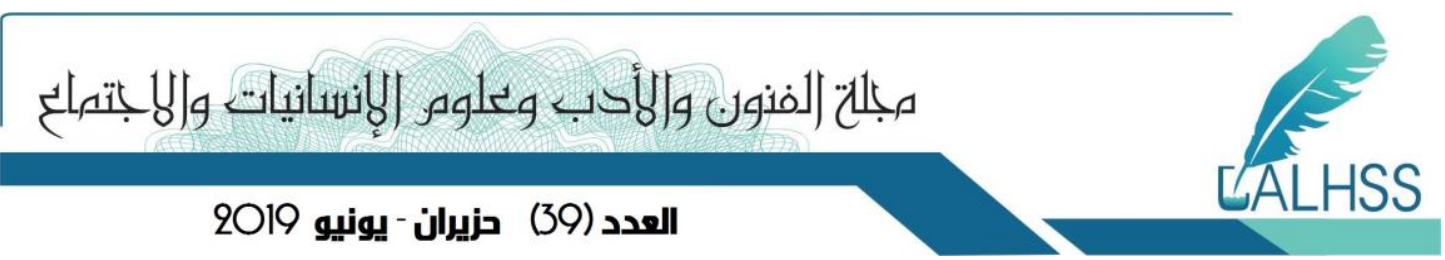

Introduction:

In the outline of a free economy and the control of market mechanisms, the consumers have become subject to manipulation of their interests and attempted fraud. The seller may overlook the safety and security of the consumer by making it unrealistic in its production. Since the risk to consumers of e-commerce is greater than the risk in traditional trade because the scope of electronic commerce is broader than traditional trade.

Hence, the need for consumer protection in the online marketplace has been emerged. Confidence in the online market is one of the most important needs of consumers in order to meet their personal needs. Where the legal protection of the consumers in the pre-contract stage or at the stage of the conclusion of the electronic contract, or at the stage of implementation of the electronic contract is considers very essential because the consumers can be a weak part in conducting the electronic commerce contract. In that case, it may need a certain product and subject to unusual and unfair conditions because the seller is the strong part of this decade (Nasr, 2005).

\section{Study problem:}

The study problem is an attempt to answer the following questions: what is ecommerce? Moreover, how can it use to make its features? What are the advantages and benefits of e-commerce?

\section{The importance of the study:}

After the huge developments in the global trading areas, and after the congestion of the markets in various companies and diversified, and after the intensification of competition between these companies to achieve profits and move forward. The importance of this study is to identify the importance of this trade by knowing the benefits of using it to increase the efficiency of the companies. The importance of this study is also important to identify how e-commerce works in providing these benefits to companies.

\section{The Objectives of this study:}

This study aims to:

1. Understand the concept of electronic commerce. -

2. Identify the reasons for Consumer Protection.

3. Identify the benefits of using e-commerce. 


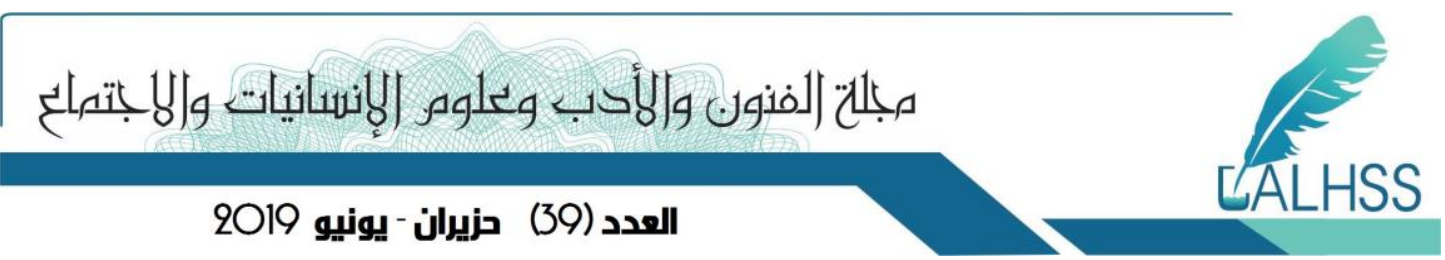

\section{The concept of electronic commerce:}

Electronic commerce is the implementation and management of business activities related to goods, services by data transfer over the Internet or technical systems. E-commerce also defined as a new concept that explains the sale, purchase or exchange of products, services and information through computer networks, including the Internet (Tishuri, 2005). It is a trade that considers not only deals with the sale and purchase of goods, but also add to other activities such as the design, supply, production, and distribution of goods and services (Kendal \& Hellerstien, 2002, 10). Is a set of integrated business processes that are handled by all events, institutions and individuals and rely on electronic processing (Dempsy, 1997, 55).

\section{Types of electronic commerce:}

1. Business to Business (B2B).

2. Business to Consumer (B2C).

3. Business to Government (B2G).

4. Government to Consumers (G2C).

5. Consumer to Consumer $(\mathrm{C} 2 \mathrm{C})$.

\section{The general concept of electronic consumer protection}

In electronic transactions, contracting is online; the product is not in the hands of consumers. Given the significant risks involved in the consumer process at all stages, and to protect consumers from the risks of their goods and services in addition, to prevent them from falling prey to consumerism. Therefore, the law must be subject to consumer protection in electronic transactions. Besides, putting the necessary tools to rebalance the consumer relations in order to bring harm and danger to the consumers.

Consumers defined as a person who obtains or use goods or services for unprofessional use. Electronic consumer is the person who contracts various electronic contracts of purchase lease, loan and uses in order to obtain all the necessary goods and services to satisfy his personal or family needs, without intended to be marketed and without having the technical expertise to deal with such matters.

Electronic contracts are international, cross-border, non-State, commercial, civil or mixed in the nature of the relationship between the parties of the contract. The law applicable to the electronic contract is the will law means the law chosen by the parties. As the writing needs to be signed by the parties to indicate their consent to the content, the signature of electronic contract is of several forms due to its nature, and that it is through electronic means, such as the signature biometric, digital, electronic pen signature, etc. Granting an authentic electronic signature is closely related to the degree of safety available to stakeholders. Therefore, legislations seek to impose 


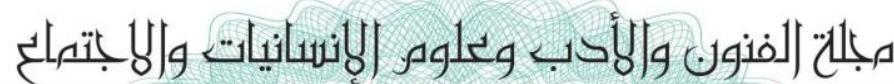

العدد (39) حزيران - يونيو 2019

certain conditions on the electronic signature to give it the authoritative evidence and there was a convergence of these laws in their terms.

\section{Benefits and Advantages of E-Commerce:}

1. More effective marketing: E-commerce allows enterprises to display their products and services in different corners of the world.

2. Speed, time, simplicity and ease: business transactions for goods and services between companies and consumers are often quick because of the speed depending on the Internet (Waelbb, 2003, 2).

3. Effective communication with partners, customers and suppliers: The direct relationship between the product and the customer or the facilities allows for better services.

4. Access to international markets: The global character of e-commerce has abolished the limits and restrictions on entering commercial markets. As a result, the world has become an open market for consumers regardless of the geographical location of the seller or purchaser.

5. Reduction of corporate expenses: Preparing and maintaining e-commerce sites is more economical than retail or office maintenance. Companies do not need to spend too much on promotional items, or install expensive equipment for customer service (Waelbb, 2003, 2).

\section{Reasons for Consumer Protection:}

Is because of the lack of consumer information technology enlightenment, the consumer need for e-services in the means of shopping and communication. In addition, the impact of the modern development of the Internet on the consumer, as shown below:

\section{Modern development on the Internet:}

When computers became more powerful in the late 1980s, businesses increasingly used them to build their own internal networks (Smith, 2000). The technical development in this aspect is a scientific reality that comes every moment with new that should lead to improved business linkages between the provider and the consumer in order to achieve the best performance of e-business practices. The downside of this technological development, however, is the fact that consumers are oppressed in a seemingly hostile way (Badr, 2005). Which should affect the legal description of the online commerce contract over the Internet as opposed to the sale that takes place in the home and place of residence of the consumer. This is the inability of the consumer to preview the sale in a real way or to meet with the supplier in a traditional contractual council (Tariq, 2003). 


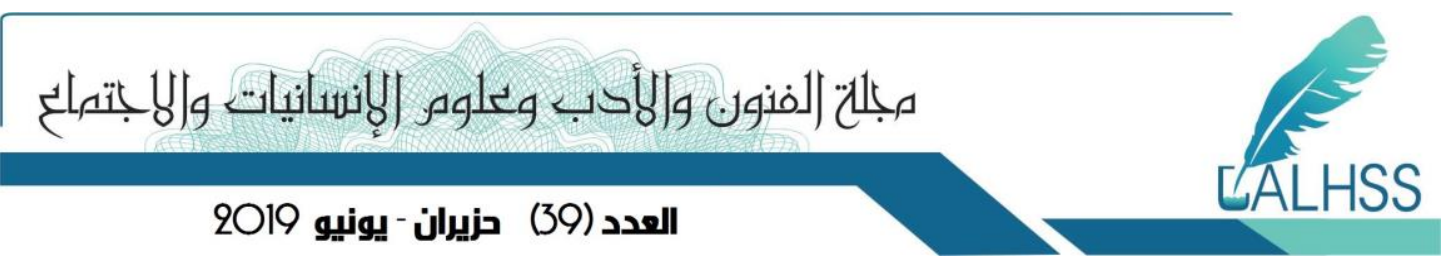

\section{Consumer need for e-services:}

Lack of consumer e-services makes them unable to interact with commercial sites over the Internet. The lack of consumer awareness of commercial sites over the Internet is due to the lack of need for these sites (Tariq, 2003). However, with the development of these sites has become very important. It took many forms, including real estate, tourism, banking, insurance, ticket sales, hotels, and other important services. The consumer's need for electronic services stems from the fact that they provide high-quality products and services at reasonable prices due to a large number of commercial websites, thus increasing the competition between these sites to provide the best for the consumer (Momani, 2004).

\section{Consumer lack of technical information enlightenment:}

The ability of the consumer to deal with the computer and the Internet makes it easier for him to access the products and services he/she wants. Lack of consumer may be a lack of knowledge of the Internet. In addition to the problems that may face the consumer when the depth of this network (Mamdouh, 2010). This is done by facing the consumer not knowing what is happening on the small screen. In addition to the above, the lack of knowledge of the Internet may lead to the fall of the consumer tricks and artifice Internet hackers through phantom sites or imaginary contracts. Therefore, the consumer's need for protection in e-contracting also stems from the fact that the consumer is the least experienced and knowledgeable party in ebusiness transactions and the least powerful in the economic equation (Badr, 2005).

\section{Consumers need legal protection:}

Consumers need legal protection because of risks, lack of security, and the proliferation of problems over the Internet. Consumer protection in e-contracting is one of the most important topics that need to be considered. The world became a large market within a small computer screen, through Consumers can desired location and realize the terms of purchase, contracting, access to the item, or the specific service. On the other hand, the emergence of large economic conglomerates in the electronic market has alerted many countries to accelerate the development of legislation based on consumer protection in electronic contracting.

\section{Consumer Protection in Comparative Law:}

Countries have initiated the issuance of a law on electronic commerce transactions, including provisions for consumer protection, for instance:

French consumption law: The French legislator issued the new French consumption law No. 949-93 on July 26, 1993, which consists of five parts related to consumer 


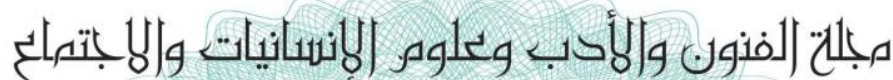

العدد (39) حزيران - يونيو 2019

information and protection, the organization of consumer associations, conformity, and safety of products and services.

The e-commerce law of the Duchy of Luxembourg: The e-commerce law of the Duchy of Luxembourg contains provisions for consumer protection. The most important is the consumer information about the supplier's information, the specifications of the goods and services, the currency in which the payment is made, the duration of the bid, the price, the terms of the loan and the consumer's right to cancel the contract.

E-commerce law in Italy: the e-commerce law in Italy mandated suppliers to inform consumers of the detailed specifications of the goods or service, including electronic taxes, in a timely manner before concluding the contract.

Law of Transactions and Electronic Commerce of the Emirate of Dubai: The law of transactions and electronic commerce No. (2) for the year 2002 to the Emirate of Dubai with the aim of replacing the modern technical means in commercial transactions instead of conventional means. Among its provisions were the electronic transactions statement and the establishment and validity of contracts.

Egyptian Electronic Commerce Law: The law protecting the personal data of any citizen in the State deals with the Internet. The government provides full protection of consumer data without concern about its theft or use in illegal places. Moreover, Electronic Transaction Law that is a law will maintain business transactions through the development of various regulatory policies.

Jordanian Electronic Transactions Law: Electronic Transactions Law No. 85 of 2001 - Jordan. This law aims to facilitate the use of electronic means.

Iraqi Law of electronic signature and electronic transactions: Iraqi Law of electronic signature and electronic transactions No. (78) for the year 2012. The Iraqi law defined the electronic contract as a relationship of affirmation issued by one of the contractors to accept the other, in a manner evidencing its effect in the proceedings held on it, by electronic means. Iraqi law aims the following. Provide the legal framework for the use of electronic means in conducting electronic transactions. Enhance confidence in the authenticity and integrity of electronic transactions. Grant the legal authenticity of electronic transactions and electronic signature and organization of its provisions.

\section{Findings:}

E-commerce is one of the most important modern features in the knowledge economy and its main engine as well as it represents the fastest-growing sector "in the global economy. E-commerce has become a "tangible" reality in the current environment. Its 
role expected to increase in the near future due to its effective impact on the business environment. The global features of electronic commerce abolished the limits and restrictions to enter the commercial markets. The world has become an open market for consumers regardless of the geographical location of the seller or buyer. In addition, the characteristics of electronic commerce and the increase in the rate of Internet users have resulted in the rapid spread among many producers and consumers and the development of the volume of electronic commerce at the global level.

Moreover, this study found that all efforts should be made to develop and prosper ecommerce, whether at the local or international level, also whether at the level of governmental or non-governmental organizations. Barriers to the existence of closed international markets should remove from electronic commerce, in order to maximize the advantages of e-commerce

\section{Recommendation:}

1. Getting support for the concept of e-commerce throughout the company is a very important issue.

2. Take advantage of the experiences of the countries that have been involved in this field.

3. The necessary to develop a national e-commerce strategy and translate it into work programs carried out under the supervision of a specialized technical committee in this field.

4. Implementing the legal rules as exists in the laws for protecting consumers in Ecommerce.

5. The need to issue the necessary legislation to control the dealings within the field of e-commerce in order to prevent fraud, antitrust and the protection of private secrets of producers and consumers. All of this leads to confidence for all ecommerce clients.

\section{References:}

- Badr, O. A., (2005) Consumer Protection in Electronic Contracting. First Edition. New University House for Publishing, Egypt.

- Dempsy ,D, (1997)," what is electronic commerce" ,USA,march.

- Kendal. H. and Hellerstien, W., (2002) Electronic commerce: Perspectives on proposals for change and their constitutionality, Brigham Young University law review, USA.

- Mamdouh, K., (2010) Consumer Protection in e-Commerce Contracts, Dr. Khaled Mamdouh's website on Kenana Online.

- Momani, B. T., (2004) Problems of online contracting. First Edition. Jordan: The World of Modern Books, Egypt. 


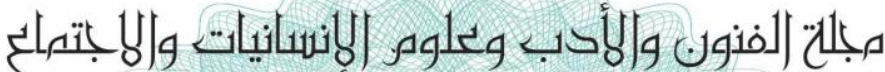

\section{العدد (39) ريران - يونيو 2019}

- Nasr, S. (2005) Economic Dimension for Consumer Protection, Paper presented to the Forum of Women and Consumer Protection, National Council of Women, Cairo, Egypt.

- Smith, G. R, "Confronting Fraud in the Digital Age", Paper presented at the Fraud Prevention and Control Conference, the Australian Institute of Criminology in association with the Commonwealth Attorney-General's Department, Surfers Paradise, 24-25 August. (2000).

- Tariq A., (2003) E-Commerce - Concepts - Experiences - Challenges Technological, Financial, Marketing and Legal Dimensions. First Edition. University House. Egypt.

- Tishuri, A., (2005) "Electronic Commerce and its Expected Effects," Urban Dialogue, Issue 13. 